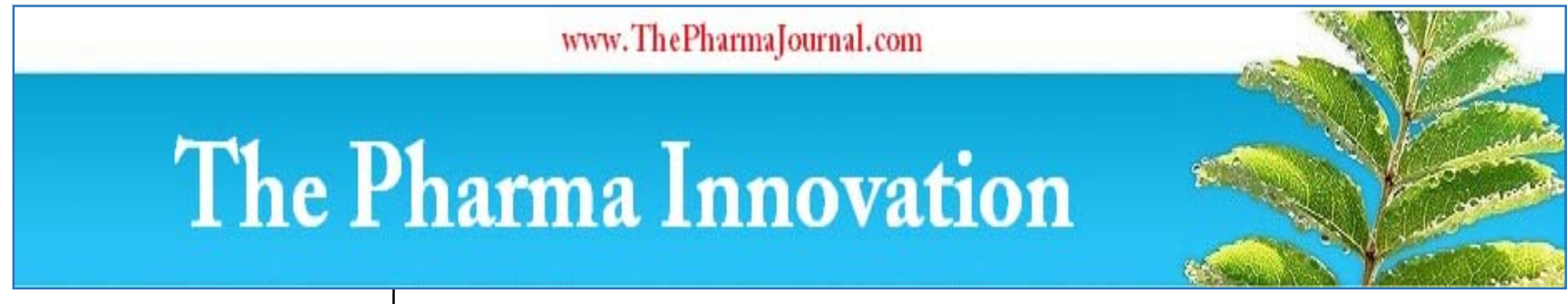

ISSN (E): 2277 - 7695

ISSN (P): 2349-8242

NAAS Rating: $\mathbf{5 . 0 3}$

TPI 2020; 9(9): 160-163

(C) 2020 TPI

www.thepharmajournal.com

Received: 24-07-2020

Accepted: 25-08-2020

Nabaneeta Gogoi

Professor and Principal Scientist, AICRP (Home Science),

Department of Textiles and

Apparel Designing, College of

Community Science,

Assam Agricultural University,

Jorhat, Assam, India

Smita Bhuyan

Assistant Professor, Department of Textiles and Apparel

Designing, College of Community

Science, Assam Agricultural

University, Jorhat, Assam, India

\section{Medical textiles: It's present and prospects}

\author{
Nabaneeta Gogoi and Smita Bhuyan
}

DOI: https://doi.org/10.22271/tpi.2020.v9.i9b.5105

\section{Abstract}

The textile industry is one of the oldest and the second largest employment generated sector in India and it covers a wide range of products from traditional textiles, household textile, woven, knitted, non- woven and technical textiles. Textile products that have wide use in different sectors like agriculture, healthcare, engineering, safety, etc. all are under the umbrella of technical textiles. It is one of the emerging and indispensable parts of the textile industry, in the field of medical, hygiene, and health care sector. Medical textile is a together effort of the textile and healthcare sector to protect and care for the human being and also protecting itself especially in the time of the global pandemic like Covid-19. The number of applications in medical fields is limitless and diverse, ranging from personal protection kit, a single thread suture to the complex composite structures from implantable structure to non- implantable ones. Besides these, finishing of textiles with natural materials can also enhance some properties of fabrics like antimicrobial, antibacterial, etc. that can hinder various infections. The main objective of this paper is to study the importance of medical textiles in the present scenario as well as in the future days.

Keywords: Textiles, medical textiles, finishes, antimicrobial

\section{Introduction}

Industrialization, globalization, and modernization-all the steps had developed the world but along with these new diseases are also emerging in human life which required healthcare. Healthcare is the service provided by health professionals for the benefit of patients and is used for prevention, treatment, and management of illness, the prevention of mental, problems, and promotion of general well-being of man through the services offered by the medical and health specialist (Martin, 2010) ${ }^{[11]}$. With the medical textile market predicted to grow at a CAGR (compound annual growth rate) of 4.23 percent during the period 2018-2022, the industry is positioning itself to meet this demand (Mahony, 2019) ${ }^{[15]}$. Besides disease, accidents major and minor, natural disasters are also causing a risk to mankind. To overcome these, new textile materials are required in medical fields. Medical Textiles is one of the needed sectors in the field of technical textiles market ranging from simple gauze or bandage materials to implants. The use of technical textiles in proper protection of the health worker is becoming a prime important during the pandemic as the virus is very different and can easily spread from the infect to the healthy person through different media. If proper protection is provided to the health care person, than only he can help the patients. For the combination of textile and medical science, textile technologist, and medical profession researched together to form medical textiles, this is a new field for both the medical and textile sector. As per todays' need, the new areas in the application of medical textiles are researching and new fiber along with improved technology for fiber, yarns, and fabrics are emerging. As per the basic requirement and the comfort ability level, the technical textiles are developed based on their end-use with the use of natural or manmade fibers, natural fiber is most favored. But today's world is more conscious about natural products which are ecofriendly and are less harmful and less bad harmful effects in the future.

\section{Medical textiles}

Technical textiles include textiles for automotive applications, medical textiles, geotextiles, and protective textiles. Overall global growth of textile ranges about 4\% per year (Khan, 2013). Healthcare and hygiene both are important sectors among other medical applications. The different types of products are made for the healthcare sector, construction, manufacture such as in operation theater construction, but the textile should meet the basic requirements such as hygienic, comfortably, and safety. They could either be washable or disposable.

$$
\sim 160 \sim
$$




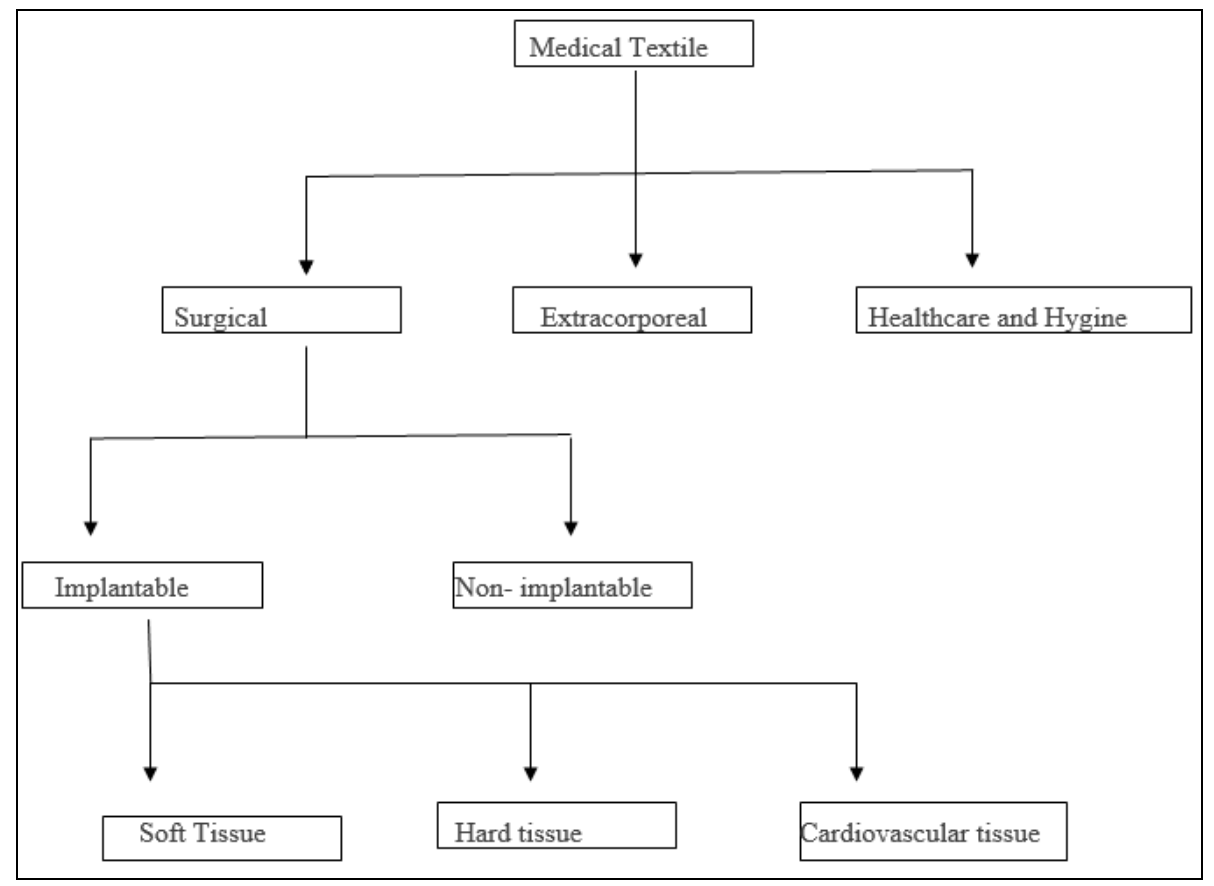

Fig 1: Classification of Medical Textiles According to Akhter, et al. 2014

A possible source of infection to the patient is the pollutant particle shed by surgical gowns and masks that act as a barrier which hinder the entrance of the bacteria and act as a barrier. Along with these, it should be comfortable, less expensive, etc. Nowadays, Personal protection equipment is used by doctors, nurses, lab workers, and all the individuals associated with COVID-19 patients. Since prehistoric time natural medicine, roots, bark, creepers, and leaves of trees are used for wound treatment, bones attachment, etc. which paved the way for natural medical textiles and uses of textile finishes for various treatments. But in today's' time, surgery is made possible by the insertion of implantable materials replacing a portion of bones, tissues, etc. Implantable materials are used in implanted the human body and can effectively repair to the body whether it is wound closure (sutures) or replacement surgery (vascular grafts, artificial ligaments, etc.) Sutures are mono or multifilament threads used of close wounds, join tissue, etc. Soft tissue implant used biomaterials. Fibers such as bio-glass fibers are used in tissue engineering which is used to create new bone structures, and textile scaffolds are being used to promote cell growth and build cell structures. Textile based stents - small cylindrical tubes made from biocompatible materials are used to support and keep veins and arteries open. Both types of stunts are used some are absorbed by the body after would healing basically from 15 -
30 days while other types are permanent and become a part of the body or are taken after completion of healing (Ahmed, 2004) ${ }^{[10]}$. The textile materials should offer strength and flexibility. In the case of hard tissue implants, it should make of compatible material that has excellent mechanical properties like good process ability, biocompatible, etc. for eye tissue natural and synthetic hydro-gel are used to reassemble the eye tissue. New textile fiber technology such as the development of new smart garments could be improved by wearing compliance, signal accuracy, and better health care for the consumers.

Non- implantable materials are used for protection against infection, absorption, healing applications, etc. The products are prepared according to the usability; some are used bandages for the external application only while materials like threads for inner stitching is used mainly of silk-like protein fiber which can be absorbed in the body system. They should be generally soft and pliable, easily applicable and removal, etc.

Extracorporeal devices are used as mounted devices used to support the function of vital organs, such as kidney, liver, lung, heart pacer, etc. there are different extracorporeal devices used in the human body such as artificial organs, tissues, etc.

Table 1: Fibers used for different purposes

\begin{tabular}{|c|c|c|}
\hline Fiber & Type of construction & Uses \\
\hline Cotton, viscose, Lyocell & Non-woven & Absorbent pad \\
\hline Alginate fiber, chitosan, silk, & Woven, non-woven, knitted & Wound-contact layer \\
\hline Viscose, Lyocell, plastic film & Woven, nonwoven & Scaffold \\
\hline Polylactide fiber, polyglycolide fiber, carbon Spunlaid, & Needle punched nonwoven & Wadding \\
\hline Cotton Woven Lint Viscose, cotton linters, wood pulp & Non-woven & Gauze dressing \\
\hline Cotton, viscose, lyocell, Alginate fiber, Chitosan & Woven, nonwoven, knitted & knitted Plasters \\
\hline $\begin{array}{c}\text { Cotton, viscose, plastics film, polyester fiber, glass fiber, } \\
\text { polypropylene fiber }\end{array}$ & Woven, non-woven, & Simple non-elastic and elastic bandages \\
\hline $\begin{array}{c}\text { viscose, lyocell, cotton } \\
\text { Cotton, viscose, Lyocell, polyamide fiber, elastomeric-fiber } \\
\text { yarns }\end{array}$ & Woven, non-woven \\
\hline
\end{tabular}




\begin{tabular}{|c|c|c|}
\hline $\begin{array}{l}\text { Cotton, viscose, Lyocell, elastomeric fiber yarns Woven, non- } \\
\text { woven, knitted High-support bandages }\end{array}$ & Woven, non-woven, knitted & High-support bandages \\
\hline Collagen, catgut, poly glycolide and polylactide fiber & $\begin{array}{l}\text { Monofilament, braided } \\
\text { Biodegradable }\end{array}$ & Sutures \\
\hline Polyester, carbon fiber & Braided & $\begin{array}{l}\text { Artificial ligament Low density } \\
\text { polyethylene fiber }\end{array}$ \\
\hline $\begin{array}{l}\text { PTFE fiber, polyester fiber, silk, collagen, polyethylene fiber, } \\
\text { polyamide fiber }\end{array}$ & Woven & braided Artificial tendon \\
\hline $\begin{array}{l}\text { Polyester fiber, polyamide fiber, PTFE fiber, polypropylene } \\
\text { fiber, polyethylene fiber }\end{array}$ & Monofilament, braided & Non-Biodegradable sutures \\
\hline Cotton, polyester fiber, polypropylene fiber, viscous & $\begin{array}{c}\text { Woven, nonwoven Surgical } \\
\text { gowns }\end{array}$ & $\begin{array}{c}\text { Woven, nonwoven Surgical gowns, caps, } \\
\text { surgical mask, surgical drapes }\end{array}$ \\
\hline Outer layer Viscose, Lyocell Nonwoven Cloths/wipes & $\begin{array}{l}\text { Outer layer Viscose, Lyocell } \\
\text { Nonwoven Cloths/wipes }\end{array}$ & $\begin{array}{l}\text { Outer layer Viscose, Lyocell Nonwoven } \\
\text { Cloths/wipes }\end{array}$ \\
\hline Cotton, polyester fiber, polythene & Woven, knitted & $\begin{array}{l}\text { Blankets, bed sheets, pillow cover, } \\
\text { uniforms, diaper sheet }\end{array}$ \\
\hline Hollow polyester fiber, hollow viscose, hollow polypropylene & & Artificial kidney, liver, Mechanical lung \\
\hline
\end{tabular}
(Chinta S K et al. 2013) $^{[13]}$

The major points to be requirements for biomedical polymers are non-toxic and non-allergic nature, mechanical properties like strength, elasticity, durability, biocompatibility nature. As biomedical materials should not be able to contaminate with bacteria. Sterilization is essential and important for biomedical polymers.

\section{Application of non -woven Materials}

Non- woven materials are made without using the techniques of basic fabric construction i.e. weaving or knitting. They are made by using the technique of felting, bonding, braiding, etc. which are used in the medical and healthcare sectors. The advantage of using non-woven is because of its cost, hygienist, and less time requirement. The adhesive bonded method of non- woven method is mainly used for the hospital; use and also in the manufacturing of sanitary napkins, diapers for both baby and adult which can be thrown away after use. Different natural fibers are used for sanitary napkins, to limit the incidence of cross-infection. The properties like comfort, absorbency, softness, lightweight is a must for construction of health care products, which can be fulfilled by using of low bulk density non-woven fabrics

\section{Textiles finishing}

Textile finishing is a technique of increasing the desirable properties of the fabric. Functional finishes or special purpose finishes have applied to the textile materials for enhancing its performance properties but they do not alter the appearance of textiles (Amayappan.L et al. 2019) ${ }^{[8]}$. Textile serves as a middle material or a lining between the environmental microorganism and the human skin. It is also a carrier of microorganism, if not washed properly after use which can create health-related problems. These micro-organisms also diminish the fabric quality and appearance by creating discoloration, stains, and sometimes fiber damage, unpleasant odor and a slick, slimy feel (Hein et al. 2013) ${ }^{[3]}$. Hence to protect the wearer and also the fabrics from infection, textile fabrics can be finished with different antimicrobial agents. Antimicrobial textiles can improve functional properties like infection control, barrier material and can also be used in a variety of applications such as health and hygiene products, etc. (Malpani. S 2013) ${ }^{[2]}$. Antimicrobial finished if done with herbal extract it will be eco-friendly and will have no other health-related problems. The antimicrobial finish obtained from the herbal extract is one of the types of special finishes, applied to the textile material. The textile material is capable of protecting the skin of the wearer. Antibacterial fabrics can be used as daily wear which reduces the effect of protecting the wearer from bacteria and can also act as. The microbial growth can reduce the microbial activities and thus makes the fabric microbial resist (Jakimiak et al., 2006). The herbal extract is extracted from different plant sources and India is an evergreen land with varieties of plant and among them 45,000 plant species which have been identified. More than 15-20 thousand identified plants are having good medicinal value and some plants are used by our ancestors for curing different diseases. According to a finding of the World Health Organization (WHO) said that in developing countries still, more than $80 \%$ of the people depend on traditional medicine for minor diseases or their primary health needs. About $75 \%$ of the medicinal needs are satisfied by 6000 traditional plants in India (Kumudhavalli.et.al 2010) ${ }^{[16]}$. Different plants or parts of plant extracts are used for use in textile finishes. They can be used as textile finishing agents either by direct application or by using pad-dry cure method or as microcapsules form. The finishes by the direct application are less durable than microencapsulation. Based on their antibacterial efficacy, the herbal extracts with higher antibacterial activity were selected and used for the preparation of microcapsules (Thilagavathi, G., 2017). The same treatment given to a fabric can be used for antimicrobial compounds and also for curing of disease. Such as leaf and stem of $\mathrm{T}$. bellerica are more active against Gram-positive bacteria and the research is also carried out to inhibit the gram-negative bacteria by using plant extracts. As per Chanda et al. 2019. Application of Ginger and curry leaf extracted essential oil by pad-using pad dry-cure method on cotton fabric can be a good antimicrobial finish.

According to Jain et al, 2009 mostly nanoparticles reveals completely new or improved properties based on explicit characteristics such as size, distribution and morphology. The herb loaded nanoparticles using antimicrobial finishes defeat the drawbacks of chemical finishes. They will not cause damage to the fabrics, are ecofriendly, non-toxic, non-allergic because naturally occurring herbs are used, the cost factor is also reasonable. The Glide wear fabric which works as a layer of protection between the head and helmet with freedom of air movement, which works by Inspiring from cerebrospinal fluid acts as a protective layer by inserting between the human brain and the skull. Screen print electrodes work as bio potential monitoring such as electrocardiogram which adhered to a garment. These garments are investigated by Jesse Jur's research team, called NEXT, at NC State Wilson College of Textiles, as a platform 
for understanding the challenges between the garment construction and electronics summit.

\section{Conclusion}

The application of medical textiles is increasing and new techniques are advancing. Medical textiles are very important textiles to protect the health workers from emerging transmitted diseases. New fabrics are also innovating which can protect the wearer from accidents. Fabrics are treated with natural extract by different methods like direct methods, nanoparticles, pad, and dry cure methods, microencapsulation methods are also capable of protecting the wearer. But we can think of developing different medical textiles like reusable and comfortable PPT kit. So, the cost of procuring personal protecting equipment is reduced, and also the wearer feels comfortable while wearing.

\section{Reference}

1. Jakimiak B, Röhm-Rodowald E, Staniszewska M, Cieślak M, Malinowska G. Kaleta Antimicrobial Activity of Terminalia bellerica Leaf and Stem Collected from Two Different Sites Sumitra Chanda*, Disha Menpara and Dishant Desai American Journal of Phytomedicine and Clinical Therapeutics AJPCT "Testing for Antimicrobial Activity in Textiles - Quick Overview", www.biovation.com 2013; 1(9):721-733

2. Malpani S. "Antibacterial Treatment on Cotton Fabric from Neem Oil, Aloe Vera \& Tulsi”, International Journal of Advance Research in Science and Engineering, $2013 ; 2: 35-43$.

3. Hein N, Hnin S, Htay D. "A Study on the Effect of Antimicrobial Agent from Aloe Vera Gel on Bleached Cotton Fabric", International Journal of Emerging Technology and Advanced Engineering. 2003; 4:7-11.

4. Hooda S, Khambra K, Yadav N, Sikka VK. "Antimicrobial activity of herbal treated wool fabric", American International Journal of Research in Formal, Applied \& Natural Sciences, 2013, 66- 69.

5. Jaswal P, Agya Preet S, Goel G. Antimicrobial activity of herbal treated cotton fabric. International Research Journal of Engineering and Technology (IRJET) e-ISSN: 2395-0056 04 2017, 45

6. Nithyakalyani D, Ramachandran T, Rajendran R. Biosciences Biotechnology Research Asia, 2017, 23950072

7. Thilagavathi G, Krishna BS, Kannaian T. Microencapsulation of Herbs for Wound Care Textiles Microencapsulation of herbal extracts for microbial resistance in healthcare textiles. Indian Journal of Fibre and Textile Reseach. 2007; 32:351-4.

8. Amayappan L, Pan N, Khan A, Bhowmick S. Functional finishing of jute based textiles, Advances in product diversification and waste utilization of natural fibers. 2019, 156-164.

9. https://www.technicaltextile.net/articles/medical-textiles2587 retrived on 22nd August 2020

10. Juliani HR, Simon JE . Antioxidant activity of basil. In J. Janick, \& A. Ahmed, F Developments in Health Care and Medical Textiles - A Mini Review, Pakistan Journal of Nutrition 2014; 13(12):780-783, 2014, ISSN 1680-5194

11. Martin EA. Meaning of health care. Concise medical. Dictionary Oxford Paperback, 2010.

12. Medical Supplies and Equipment Company Surgical gowns. protection and comfort Accessed on 28 March
2015 from http:company.corn/pdf/pagelDV19/ article.asp. 2013.

13. Chinta SK, Veena KV. Impact of Textiles in Medical Fiel International Journal of Latest Trends in Engineering and Technology. 2013; 2(1):142-145.

14. Luniak B. The identification of textile fibres: qualitative and quantitative analysis of fibre blends, 1953.

15. Mahony OM. Advances in smart medical textiles, Speciality fabric review, IFAI publications, 2019

16. Kumudhavalli MV, Vyas M, Jaykar B. Phytochemical and pharmacological evaluation of the plant fruit of Terminalia belerica Roxb. Int J Pharm Life Sci. 2010; 1:1-11.

17. Alexandria VA. ASHS Press.Microbiological assessment of efficiency of antibacterial modified textiles. Roczniki Państwowego Zakładu Higieny, 2006; 57(2):177-84.

18. Whipkey. (Eds.) Trends in new crops and new uses 2009 , 575-579. 